JOANNA CIESIELSKA-KLIKOWSKA

Uniwersytet Łódzki

ORCID: 0000-0003-0938-5771

joanna.ciesielska@uni.lodz.pl

\title{
Cooperation of German cities with Chinese partners and its importance for Germany's foreign policy
}

Współpraca miast niemieckich z partnerami chińskimi i jej znaczenie dla polityki zagranicznej RFN

Słowa kluczowe: miasta, paradyplomacja, dyplomacja miast, relacje niemiecko-chińskie
Keywords:

cities, paradiplomacy, city diplomacy, GermanChinese relations 


\section{Współpraca miast niemieckich z partnerami chińskimi i jej znaczenie dla polityki zagranicznej RFN}

XXI wiek to czas ogromnego rozwoju miast jako aktorów politycznych, gospodarczych i społecznych aktywnie kształtujących scenę globalną. Niemieckie miasta są ważnymi aktorami na międzynarodowej arenie politycznej, gdyż posiadają szerokie kompetencje do prowadzenia polityki zagranicznej, wynikające z systemu federalnego. W ciągu ostatnich lat szczególnie dynamicznie rozwijały one swoje kontakty z miastami chińskimi. Dla miast niemieckich ich chińscy partnerzy stali się zarówno kooperantami w zakresie rozwiązań administracyjnych i gospodarczych, jak i coraz częściej współpracownikami w kwestiach edukacyjnych i kulturalnych.

Celem niniejszego artykułu jest zmapowanie powiązań miast niemieckich i chińskich, a następnie odniesienie się do miejsca, jakie zajmują stosunki międzynarodowe prowadzone przez podmioty subpaństwowe w polityce zagranicznej realizowanej na poziomie federalnym. Punktem wyjścia do analizy jest przedstawienie roli dyplomacji miejskiej, a następnie wyników ankiet przeprowadzonych wśród urzędników reprezentujących niemieckie miasta zamieszkane przez co najmniej 50 tys. mieszkańców. Autorka przedstawi warunki współpracy bilateralnej między miastami, kluczowe obszary współpracy, determinanty sukcesu oraz najczęstsze problemy. W ostatniej części zawarta jest analiza roli miast w niemieckiej rzeczywistości politycznej. Pozwoli ona ocenić, czy działania wobec chińskich partnerów są skoordynowane z innymi instytucjami na poziomie regionalnym i krajowym.

\section{Cooperation of German cities with Chinese partners and its importance for Germany's foreign policy}

The 21st century is a time of enormous development of cities as political, economic and social actors actively shaping the global scene. Among them German cities are important actors on the international political arena, as they have extensive competences to conduct foreign policy, resulting from the federal system. Over the past years, contacts of German cities with Chinese entities have experienced a particularly dynamic development. For German cities their Chinese partners have become both cooperators in terms of administrative and economic solutions, but also more and more often collaborators on educational and cultural issues.

The aim of this article is, thus, to map the connections between German and Chinese cities, and then to refer to the place which international relations conducted by sub-state entities find in foreign policy implemented at the federal level. The starting point for the analysis is the presentation of the role of city diplomacy, and then results of a survey conducted among officials representing German cities inhabited by at least 50,000 people. The author will present the conditions of bilateral cooperation between cities, key areas of cooperation, determinants of success and the most common problems. In the last part, the author will analyze the role played by cities in the German political reality. In this way, the author will indicate whether the actions towards Chinese partners are coordinated with other institutions at the regional and national level. 


\section{Introduction}

Utions rbanisation is one of the global megatrends that will decisively shape the future ${ }^{1}$. Today, more than half of humanity lives in cities ${ }^{2}$. By 2050 this will be $3 / 4$ of the world's population, i.e. around 7 billion people ${ }^{3}$. The great migration to the metropolis and the increasing rate of urbanisation worldwide indicate that change is happening right before our eyes ${ }^{4}$. Yet, cities do not operate in a vacuum. Their authorities, aware of the challenges facing global urbanisation, look for opportunities to exchange experiences and gain knowledge. This trend means that cities are beginning to play an increasingly important role in shaping the fields and sectors so far reserved exclusively for state entities, including international relations and cooperation on such levels as environmental protection, educational programs or urban transport. However, this cooperation is a phenomenon happening in the background of grand politics, on the sidelines of events shown in the media or on the margins of public interest. This does not change the fact that the cities are increasingly important non-state actors shaping the global economy, influencing international relations, and co-shaping their countries' domestic and foreign policies. ${ }^{5}$. Thus, along with the increase in urbanisation,

1 Report of the UN Economist Network for the UN 75th anniversary. Shaping the trends of our time, United Nations, September 2020, p. 72-101.

2 United Nations Population Division. World urbanization prospects: 2018 revision, World Bank, available at [accessed: 26 VII 2021]: <https://data.worldbank.org/indicator/SP.URB.TOTL.IN.ZS〉.

32018 revision of the world urbanization prospects, United Nations, Department of Economic and Social Affairs, available at [accessed: 20 IV 2021]: <https://www. un.org/development/desa/publications/2018-revision-of-world-urbanization-prospects.html>.

4 M. Szmigiera, Urbanization by continent. Degree of urbanization (percentage of urban population in total population) by continent in 2020, Statista 2021, available at [accessed: 26 VII 2021]: <https://www.statista.com/statistics/270860/ urbanization-by-continent/>.

5 J. Friedmann, The world city hypothesis, "Development and Change" 1986, vol. 17(1); C. F. Alger, The world relations of cities. Closing the gap between social science paradigms and everyday human experience, "International Studies Quarterly" 1990, vol. 34(4); J. Agnew, The territorial trap. The geographical assumptions of international relations theory, "Review of International Political Economy" 1994, no. 1(1); M. Acuto, Global cities, governance, and diplomacy, Routledge London 2013; B. Barber, 
the importance of cities in international relations and the study of states' foreign policy through the prism of their activities will grow ${ }^{6}$.

The theory of international relations (IR) has always spoken of "actors" on the international stage. Yet, the theoretical traditions that dominated IR in the mid-2oth century restricted the term "actor" mainly to uniform nation-states, which at that time were viewed as the only units that could actively shape the world order ${ }^{7}$. In the following decades, attention began to be paid to other entities determining the world scene (informal governmental ties, multinational corporations, international organisations etc.). In this regard Robert Keohane's and Joseph Nye's publication may be named, that first popularised this concept which later laid the basis of liberal paradigm of international relations theory ${ }^{8}$. The "state-centric world" in which states operate as principal agents was replaced by the diverse "multicentric world" of various state and non-state actors?

With time, the activity of cities, as non-state actors, attracted considerable scholarly attention and fell under the heading "paradiplomacy"10. Paradiplomacy is a part of an overall process of "pluralisation" of diplomacy in which diplomatic practices, institutions and discourses are no longer limited to traditional international diplomacy led by the states. Sub-state units, such as cities or regions, together with non-governmental organisations (NGOs), are the main non-state actors that engage in para-

If mayors ruled the world. Dysfunctional nations, rising cities, Yale University Press, New Haven 2013; J. J. Parysek, Duze miasta Europy $i$ ich rola $w$ procesie urbanizacji, rozwoju społeczno-gospodarczego i europejskiej integracji u schyłku XX wieku, „Przegląd Geograficzny” 1995, T. LXVII, z. 3-4; D. Szymańska, Urbanizacja na świecie, Wydawnictwo Naukowe PWN, Warszawa 2008.

6 R. Tavares, Paradiplomacy. Cities and states as global players, Oxford University Press, New York 2016, p. 8.

7 H. Morgenthau, Politics among nations, McGraw-Hill, New York 1949, p. 14; K. Waltz, Theory of international politics, Waveland Press, Chicago 1979, p. 26-30.

8 R. Keohane, J. Nye, Power and interdependence, "Survival" 1973, vol. 15:4, p. 158-165.

9 R. Keohane, J. Nye, Power and interdependence. World politics in transition, Little, Brown and Company, Boston 1989, p. 23-24.

10 N. Cornago, On the normalization of sub-state diplomacy, "The Hague Journal of Diplomacy" 2010, vol. 5 (1-2), p. 11-36; A. S. Kuznetsov, Theory and practice of paradiplomacy. Subnational governments in international affairs, Routledge, London-New York 2015, p. 9. 
diplomacy ${ }^{11}$. However, the perception of international relations still has underestimated cities as one of the key players and important objects of analysis in world politics ${ }^{12}$. This remark was the catalyst for a series of research attempts to use analytical tools to understand better the agency and role of cities in contemporary global affairs ${ }^{13}$. Nowadays, scholars argue that the diminishing importance of national borders caused by globalisation and the rigid division between domestic and international affairs have formed space for cities to engage with the international community and to create cooperative relationships with cities across borders ${ }^{14}$.

Today cities are important international actors. City governments are concerned with what has traditionally been defined as "low policy": environmental issues, investment promotion, cultural and educational exchange etc. It stays in contrast to "high policy" represented by the diplomatic and military security agenda of central government ${ }^{15}$. Hence, foreign policy ceases to be the exclusive domain of state governments. There are numerous reasons for the pluralisation of the subjective structure of international relations, i.e. democratisation of international relations, domestication of foreign policy - meaning the blurring of boundaries between domestic and foreign policy issues, socialisation of foreign policy, internationalisation of many matters within the competence of local/ regional authorities, as well as the ongoing processes of decentralisation of state administration, de-concentration of public administration functions, regionalisation and glocalisation ${ }^{16}$.

11 N. Cornago, Plural diplomacies. Normative predicaments and functional imperatives, (Diplomatic Studies, 8), Martinus Nijhoff Publishers, Leiden 2013, p. 11.

12 S. Curtis, Cities and global governance. State failure or a new global order?, "Millennium" 2016, vol. 44(3), p. 457.

13 M. Acuto, Global cities: Gorillas in our midst, "Alternatives: Global, Local, Political" 2010, vol. 35(4), p. 425-448; K. Ljungkvist, The global city 2.0. From strategic site to global actor, Routledge, London 2015.

14 B. Hocking, Patrolling the 'frontier'. Globalization, localization and the 'actorness' of noncentral governments, [in:] Paradiplomacy in action. The foreign relations of subnational governments, eds F. Aldecoa, M. Keating, Routledge, London-New York 1999, p. 17-39.

15 R. Tavares, Paradiplomacy..., p. 15.

16 A. Trzcielińska-Polus, Samorządowy wymiar polityki zagranicznej regionów (na przykładzie Śląska Opolskiego), „Pogranicze. Polish Borderland Studies“ 2015, vol. 3, no. 2, p. 119 . 
This pluralisation and increasing competencies of cities are particularly visible in the European Union. In fact, out of nearly 750 cities in the EU with more than 50,000 inhabitants ${ }^{17}$, a large part has been maintaining advanced international relations with other cities on the European continent for several decades. More and more often, along with the increasing globalisation, cities are looking for partners outside the borders of the Old Continent, very often in Asia. There is a clear trend in finding partners among Chinese cities, which have developed very intensively over the last decades.

This article draws attention to the international collaboration of European cities, based on the example of cooperation between German cities and their Chinese partners. The Federal Republic of Germany and the People's Republic of China established their sub-state relations very early - the first city-to-city relation (as well as region-to-region cooperation) was established in 1982. The first Sino-German sub-state contacts were based on the political decisions of central and regional authorities from both sides, which were related to the desire to develop economic relations and were founded on bilateral visits and the signing of partnership agreements between regions and cities. Over the next 40 years, this cooperation grew significantly and has acquired a much more complex character ${ }^{18}$.

Therefore, this article aims to present a current "map of connections" between German cities and Chinese partners. The text tries to characterise this cooperation. Thus, the main research questions revolve around the following issues:

- in which areas is this cooperation the most intense and who is its main driving force?

- What are the problems and challenges in bilateral sub-state relations?

- And finally - whether international activities undertaken by cities are correlated with foreign policy implemented at the federal level?

The research carried out as part of the project "The role of cities in the European Union's policy towards China", financed by the Polish

17 L. Dijkstra, H. Poelman, Cities in Europe. The new OECD-EC definition, European Commission, Regional Focus, nr 01/2012.

18 J. Ciesielska-Klikowska, Germany's attitude towards the Belt and Road Initiative. The impact of non-state actors on German foreign policy towards China, [in:] The Belt and Road Initiative. An old archetype of a new development model, eds P. A. B. Duarte, F. B. S. José Leandro, Springer, Singapore 2020, p. 440-444. 
National Science Centre ${ }^{19}$, is based on an in-depth literature review and statistical data gleaned from a survey on international cooperation of German cities, conducted in the last months of 2020 and the beginning of 2021 . The author, together with the research team, managed to conduct internet surveys with 79 German cities ${ }^{20}$ out of 126 that were qualified for the study, which means a return of $62,7 \%$ (cities with at least 50,000 inhabitants; list of surveyed cities is consistent with the list published by the OECD / European Commission "Cities in Europe" in 2012). A few cities refused to fill out the questionnaire or directed the research team to the region's official website to find extensive information about their international cooperation. The knowledge achieved in this way served as a supplement to the data acquired from the completed questionnaires.

This study is not the first attempt to investigate the cooperation of German and Chinese sub-state entities. In 2008, a study was conducted in Germany by Ulrich Held and Rita Merkle ${ }^{21}$, updated by Anja Goette's and Qianlan Gao's report in $2018^{22}$. Yet, this analysis is an essential supplement to their studies because it extends the perspective to the new research threads, such as cooperation with regional and central authorities. Moreover, this study is also complementary to the existing research on the cooperation between regions, which was carried out as part of an earlier project conducted jointly by the University of Lodz and the Polish Institute of International Affairs. As a result of both projects, a detailed picture of German-Chinese relations at the sub-state level was obtained, which fills the existing research gap - it can be seen that paradiplomacy should be studied through the prism of international cooperation of regions and cities, as paradiplomatic relations are carried out simultaneously on both levels.

The article is divided into three parts. The first one presents the importance of cities as actors in world politics. The second describes the results

19 Project financed by the National Science Centre under the OPUS-17 Program, project number 2019/33/B/Hs5/01272.

20 The city of Osnabrück filled the questionnaire twice giving not always overlapping data.

21 U.Held, R.Merkle, Deutsch-chinesische Kommunalbeziehungen. Motivationen, Strukturen, Aktionsfelder, Servicestelle Kommunen in der einen Welt, (Dialog Global, 19), Bonn 2008.

22 A. Goette, Q, Gao, Deutsch-chinesische Kommunalbeziehungen, Servicestelle Kommunen in der einen Welt, (Dialog Global, 19), Bonn 2019. 
of a survey conducted among representatives of German towns concerning their collaboration with Chinese cities. In the last part, the author explains the role of cooperation between municipalities in implementing German foreign policy.

\section{Cities as policy actors in international relations}

Traditional diplomacy is a centralised control of the interaction across national boundaries ahead. Cities are therefore not recognised as diplomatic personae with their own representation. That also applies to provinces or states in federal states ${ }^{23}$. However, sub-national units are becoming more and more active. The terms "microdiplomacy", "paradiplomacy", "protodiplomacy", "city diplomacy", or "town-twinning" are used to name their cross-border activities ${ }^{24}$. As Geoffrey Allen Pigman notes: "governments of large cities and metropolitan areas are more and more frequently participating directly in diplomatic activities, opening representative offices in foreign capitals or other large global cities, and more and more often sending their mayors on "state visits» to their foreign counterparts" 25 .

Therefore, the contemporary international system is characterised through the prism of two, somehow opposing, phenomena: globalization processes (defined in terms of integration and cooperation) and regional processes of world fragmentation or disintegration. Those two factors are mutually interconnected and lead to creation of a sophisticated system of international relations in which the traditionally dominant role of nation states is impugned.

The diplomatic representation of sub-national actors is nevertheless still a minor phenomenon in IR, because a large group of researchers consider states as the sole unit of research analysis ${ }^{26}$. Some scientists even call this

23 J. E. Nijman, Renaissance of the city as global actor, [in:] The transformation of foreign policy, eds G. Hellmann, A. Fahrmeir, M. Vec, Oxford University Press, Oxford 2016, p. 209-241.

24 I. Duchacek, The international dimension of subnational self-government, "The Journal of Federalism" 1984, vol. 14, issue 4; A. S. Kuznetsov, Theory and practice of paradiplomacy. Subnational governments in international affairs, Routledge, London-New York 2015 .

25 G. A. Pigman, Contemporary diplomacy, Polity Press, Cambridge 2010.

26 A. Wimmer, N.Glick-Schiller, Methodological nationalism and beyond: nation-state building, migration and the social sciences, "Global Networks" 2002, vol. 2 (4), p. 301-334. 
approach as "methodological nationalism"27. Yet, given essential role of cities in the world economy ${ }^{28}$, it is not far-fetched to assume that paradiplomacy will gain more importance in the international relations in the 21st century. In fact, the ongoing century is already a time of a significant power shift and a visible rise of cities as political, economic, and social actors that dynamically shape the global stage. Cities are intertwined with the regions around them, they also form global nodes and are parts of international networks and interdependencies, such as Local Governments for Sustainability (ICLEI) or the United Cities and Local Governments (UCLG), an international umbrella organisation of cities, local and regional governments, which has observer status at the United Nations ${ }^{29}$. Vast flows of resources in the form of energy, goods and capital, but also people and information, move between cities and their surrounding areas ${ }^{30}$. Cities are the main target of migratory movements ${ }^{31}$. In urban areas, trends in global development become apparent at an early stage ${ }^{32}$. The current urbanisation dynamics and their accompanying circumstances offer a unique opportunity to create sustainable structures. The high density of communication and contact that characterises coexistence of people in the big cities offers favourable conditions for innovative ideas and new ways of solving regional and global problems ${ }^{33}$.

The question of how the international community or national and local governments deal with the opportunities and challenges of urbanisation also has direct and indirect effects on Germany and its politics.

27 C. Jeffery, D. Wincott, The challenge of territorial politics: beyond methodological nationalism, [in:] New directions in political science. Responding to the challenges of an interdependent world, ed. C. Hay, Palgrave Macmillan, Basingstoke 2010, p. 167-188; available at [accessed: 28 IV 2021]: 〈http://orca.cf.ac.uk/39322/〉.

28 Urban world: Mapping the economic power of cities, McKinsey Global Institute, March 2011, p. 1.

29 Centenary of the international municipal movement, UCLG, available at [accessed: 25 IV 2021]: 〈https://www.uclg.org/en/centenary>.

30 R. Tavares, Paradiplomacy..., p. 22.

31 C. Tacoli, Migration and inclusive urbanization, United Nations Expert Group Meeting on Sustainable Cities, Human Mobility and International Migration, UN/POP/EGM/2017/6, 5 September 2017.

32 Migration, urbanization, and development: new directions and issues, ed. R. E. Bilsborrow, Springer, Dordrecht 1998.

33 What Policies for Globalising Cities? Rethinking the Urban Policy Agenda, OECD, Madrid 2007, p. 248-252. 
These range from global protection issues to security and stability, which cities are guarantors too. But also, the openness of markets and societies in the course of the dynamic of urbanisation are of great importance for Germany $^{34}$. This puts international urbanisation above the various crosscutting issues as a holistic task of the German foreign policy.

In German scientific literature, which analyses cross-border contacts of local government units at the sub-state level (cities, communes and Länder), and the involvement of local and state authorities (leaders and other representatives of communities) in this field, one can find many terms describing this area of activity. Albert Statz and Charlotte Wohlfahrt write about "city diplomacy" (Städtediplomatie), ${ }^{35}$, and Ernst-Andreas Ziegler uses the terms of "municipal or regional foreign policy" (kommunale und regionale Außenpolitik), "foreign policy of Länder conducted alongside the governmental policy" (Nebenaußenpolitik der Länder) ${ }^{36}$. The term "paradiplomacy", which in the world scientific literature is most often used to describe international relations conducted by sub-national governments on their own, with a view to promoting their own interests ${ }^{37}$, is practically unused by German researchers.

Yet, at the scientific level, the scholars have put a lot of emphasis on clarification of the process of German paradiplomatic cooperation, which resulted in multifaceted theoretical approaches. In one of the first comparative studies of the international role and activities of regions in democratic federal states, Hans J. Michelmann and Panayotis Soldatos examine the phenonemon of paradiplomacy in i.e. Austria, Germany, Switzerland and the United States, and evaluate the implications of paradiplomatic

34 T. Kamiński, J. Ciesielska-Klikowska, The sub-national dimension of the European Union's relations with China: A Solution for Tough Times?, [in:] Europe in an era of growing Sino-American competition. Coping with an unstable triangle, eds S. Biba, R. Wolf, Routledge, London 2021, p. 61-68.

35 A. Statz, Ch. Wohlfarth, Kommunale Partnerschaften und Netzwerke. Ein Beitrag $z u$ einer transnationalen Politik der Nachhaltigkeit, Heinrich-Böll-Stiftung, Berlin 2010, p. 68.

36 E.-A. Ziegler, Kommunale Außenpolitik, [in:] Freunde reden Tacheles. Der Beitrag der Städte zur Außenpolitik am Beispiel Deutschland-Israel, ed. E.-A. Ziegler, Verlag P. Hammer, Wuppertal 1992, p. 28.

37 N. Cornago, On the normalization..., p. 11-36. 
activities for the conduct of foreign policy in these states ${ }^{38}$. The authors explore moreover the reasons for the rise of paradiplomatic activities by non-traditional actors on the international scene.

In a newer analysis Rainer J. Schweizer and Stephan C. Brunner compare the role and competences of states in Germany and Austria, considering their position and tasks within the framework of the European Union $^{39}$. This topic is also the main theme of Simon Bulmer, Charlie Jeffery and William E. Paterson's book on Germany's European diplomacy ${ }^{40}$. The authors give a comprehensive analysis of the German role in the European Community, using a novel approach that identifies German influence in the $\mathrm{EU}$ in terms of soft power. The analysis concentrates moreover on the creation of a milieu of multilateral cooperation in which Germany's diplomatic interests could grow and affect the perception of the country abroad.

Furthermore, Andreas Langenohl presents interesting observations. His book, which is based on interviews with international urban cooperation practices in Europe, reveals the social and cultural processes that shape town-twinning as a transnational practice, but also points to its development prospects and limitations ${ }^{41}$. Also Christian Athenstaedt investigates the commitment and the numerous developments in cooperation at national and international level to prove the distribution and interlocking of competences of the various state actors, and examines the individual development policy activities of the various levels at home and abroad as well as a range of forms of interaction ${ }^{42}$.

38 H. J. Michelmann, P. Soldatos, Federalism and international relations. The role of subnational units, Clarendon Press Publication, Oxford 1991.

39 R. J. Schweizer, S. C. Brunner, Die Mitwirkung der Bundesländer an EU-Vorhaben in der Bundesrepublik Deutschland und in Österreich: ein Modell für die Mitwirkung der Kantone in der Aussenpolitik, Stämpfli Verlağ AG, Bern 1998.

40 S. Bulmer, Ch. Jeffery, W. E. Paterson, Germany's European diplomacy. Shaping the regional milieu, Manchester University Press, Manchester 2010.

41 A. Langenohl, Town twinning, transnational connections, and trans-local citizenship practices in Europe, Palgrave Macmillan, Basingstoke 2016.

42 Ch. Athenstaedt, Die Kompetenzverteilung in der deutschen staatlichen Entwicklungsszusammenarbeit Zur Zulässigkeit entwicklungspolitischer Maßnahmen deutscher Bundesländer und Kommunen, Herbert Utz Verlag, München 2011. 
Moreover, the topic of town twinning projects is developed by Albert Statz and Charlotte Wohlfarth, who assume that the idea was derived in the past from personal encounters, but now turned into business and strategic thinking model ${ }^{43}$. Their analysis searches the answer on how civil and municipal political commitment has changed lately as well as to what extent the topic of sustainability represents a future perspective in urban partnership work.

In general, the Federal Republic of Germany is very interesting in terms of research when it comes to its domestic and international politics, also in the context of relations between sub-state entities. Germany is located in the heart of Europe, is the largest country in the European Union, both in terms of demographics and economy and a key political actor on the world stage. Its political system - the federal republic - gives broad powers to regions and cities. In particular, the federal states (Bundesländer) have broad opportunities to create international relations ${ }^{44}$, but also cities (including city-states, Germ. Stadtstaaten) are becoming more and more involved in building a global network of cooperation ${ }^{45}$.

The municipalities in Germany perform central functions - they are constitutionally assured that they will regulate their local affairs freely, with the German municipal system being autonomous due to the federal structure ${ }^{46}$. Nevertheless, even in Germany, it is repeatedly criticised that due to the increasing density of regulations through higher-level

43 A. Statz, Ch. Wohlfarth, Kommunale Partnerschaften und Netzwerke..., p. 77.

44 C. Jeffery, Recasting German federalism. The legacies of unification, A\&c Black, London 1999; U. Leonardy, The institutional structures of German federalism, Friedrich Ebert Stiftung, London 1999 (electronic ed.), available at [accessed: 20 IV 2021]: <http://library.fes.de/fulltext/bueros/london/00538007.htm\#E10E15>; K.-J. Nagel, Foreign policy: the case of the German lander, [in:] Foreign policy of constituent units at the beginning of 21st century, ed. F. Requejo, Generalitat de Catalunya, Institut d'Estudis Autonòmics, Barcelona 2010, p. 121-141.

45 A. Statz, Ch. Wohlfarth, Kommunale Partnerschaften..., p. 19; J. Roters, F. Wolf, Städtekooperation und Städtediplomatie im Nahen Osten am Beispiel der Stadt Köln, „Zeitschrift für Außen- und Sicherheitspolitik“, vol. 6, no. 3, 2013, p. 331-343.

46 U. Leonardy, The institutional structures of German...; J. Plöhn, W. Steffani, Bund und Länder in der Bundesrepublik Deutschland, [in:] Handbuch der deutschen Bundesländer (2nd ed.), ed. J. Hartmann, Bundeszentr.für Polit.Bildung, Bonn 1994, p. 33-48. 
structures - the Bundesländer, federal state, and the European Union they actually have less and less room for manoeuvre and decision-making. For example, the German Association of Cities (Deutscher Städtetag) complained in a position paper on federalism reform that "the original idea of local self-government [...] in reality systematically run into the void" ${ }^{\prime 7}$. If this dictum aims at the difficulties of performing originally local tasks on the part of the cities, it applies all the more to the design of fields that go far beyond the narrowly defined space of the individual municipalities. "Big politics" therefore all too often seem beyond the reach of communal actors, who are hardly more subjects than, above all, objects of political shaping.

However, on the contrary to the assumptions of the Deutscher Städtetag, it has been clearly seen in recent years that the municipalities are given space to act, even if a broad impact is usually developed through the accumulation of a large number of municipal activities and not through the individual measures of a single municipality. One of the interesting examples of the municipal activities in an overarching context is, without a doubt, the creation of a close international partnership network. Its illustration is the German-Chinese cooperation between cities that has been progressing over the last 40 years. Its size and importance grow every years, and joint initiatives are a remarkable paradigm of the role that cities can play in the world of the 21st century.

\section{German-Chinese cooperation of cities - analysis of the survey results}

Cooperation with Chinese partners is widespread among German cities. As already mentioned, the first partnership was established in the 1980 s. On October 8, 1982, the partnership between Wuhan, capital of the Hubei Province, and Duisburg, a city in the Ruhr metropolitan area of the North Rhine-Westphalia, was officially concluded. That was the beginning of the friendly exchanges between the cities of both countries. Over the following years, several dozen of city partnerships have been formed at the provincial level. Considering the data on municipal

47 Deutscher Städtetag, Positionspapier. Kommunen im Bundesstaat stärken, sygn. 30/05/16. 
cooperation between Germany and China, 135 German entities have cooperated at the level of municipalities, cities and regions since the 1980 s with the PRC (see Chart 1).

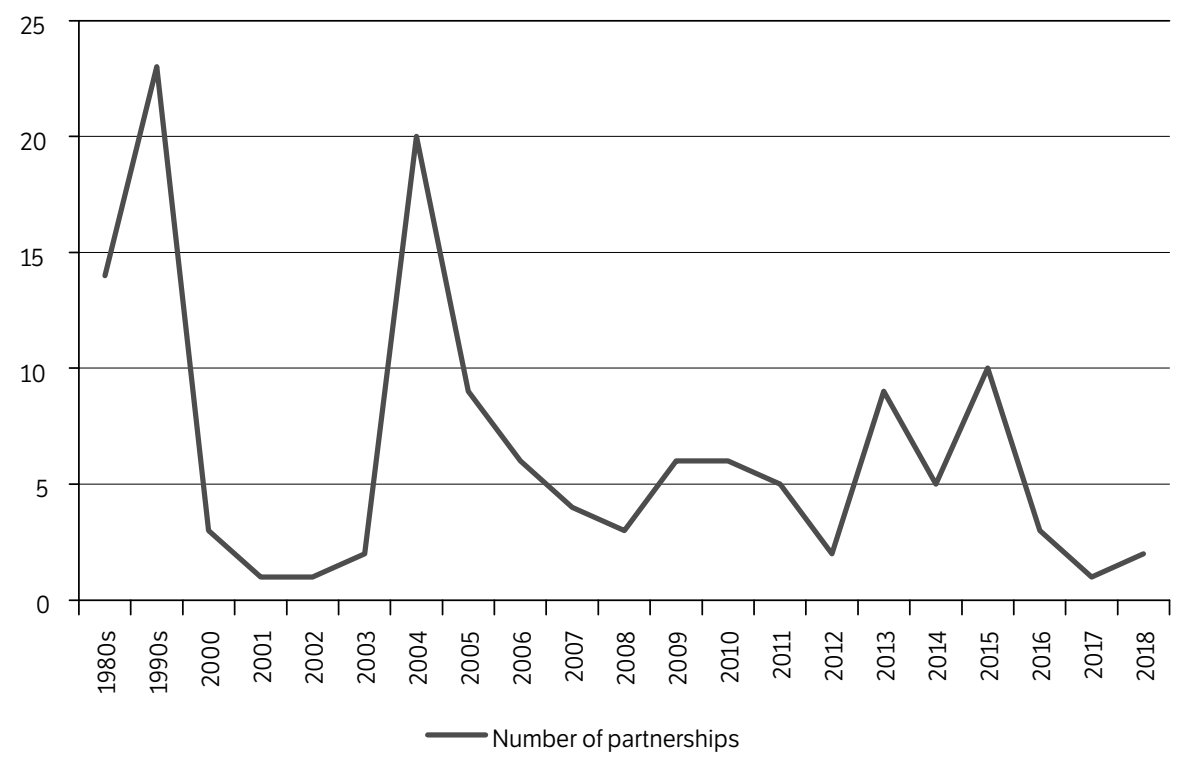

Chart 1. Number of established links between German and Chinese communes (1980-2018)

Source: own elaboration based on: A. Goette, Q, Gao, Dialog Global...; Rat der Gemeinden und Regionen Europas: https://www.rgre.de/partnerschaft/ datenbank [accessed: 24IV 2021].

The above figure clearly shows the breakthrough moments for making sub-state contacts - they were related to the policy pursued by the governments in Bonn/Berlin and Beijing. In the beginning, the flywheel for the cooperation was the Chinese policy of reforms and opening-up, implemented by Deng Xiaoping in $1978^{48}$. Yet, in the following decade, the alliance made on the highest political niveau has made sub-state contacts much easier as well. Particularly significant development of regional cooperation followed the signing of the Strategic Partnership in Global Responsibility in 2004, implementing the SinoGerman governmental consultations in 2011 and the upgrading

48 S. Huimin, W. Yi, W. Chuntai, H. Lu, China's relations with West European countries, "Studia Diplomatica" 1996, vol. 49 (4/5), , p. 149-193. 
of strategic partnership into the Comprehensive Strategic Partnership in $2014^{49}$. Interestingly, the Belt and Road Initiative - launched in $2013-$ did not fuel the building of regional cooperation, which stays in contrast to other European countries ${ }^{50}$.

When it comes to cities' partnerships only, the surveys conducted by the research team and the author of this text clearly shows how many German cities declare active international cooperation. Of the 79 cities that agreed to fill the survey, all showed that they collaborate worldwide. Three did not name their partner cities, but indicated that they are running town-twinning projects ${ }^{51}$. Moreover, 76 towns have listed a number of their most important partner cities. Cities from France, China and Poland were mentioned most often. Such extensive cooperation with these countries is not surprising - the German-French dialogue between municipalities is the basis of the Elysée Treaty signed in $1963^{52}$; a similar provision can also be found in the Polish-German treaty on good neighbourhood and friendly cooperation of $1991^{53}$; and relations with Chinese cities have been progressing very intensively since 1982 due to economic cooperation ${ }^{54}$. Italian, American, British, Israeli, Turkish and Russian cities were in the remaining places (see Chart 2).

49 Joint Declaration between Germany and China, 28. März 2014, Presse- und Informationsamt der Bundesregierung, available at [accessed: 22 IV 2021]: <https:// archiv.bundesregierung.de/archiv-de/meta/startseite/joint-declaration-betweengermany-and-china-460244>.

50 A. Skorupska, J. Szczudlik, EU-China paradiplomacy - the perspective of cities, regions and provinces, [in:] The role of regions in EU-China relations, ed. T. Kamiński, Wydawnictwo Uniwersytetu Łódzkiego, Łódź 2021, p. 16-17.

51 They probably do not have signed official partnership agreements, but the city institutions are engaged in a lively dialogue with other towns as part of specific projects.

52 G. Ziebura, Die deutsch-französischen Beziehungen seit 1945. Mythen und Realitäten, Klett-Cotta, Stuttgart 1997.

53 Wspótpraca transğraniczna Unii Europejskiej. Doświadczenia Polski i Niemiec, eds G.Gorzelak, J. Bachtler, M. Kasprzyk, Wydawnictwo Naukowe Scholar, Warszawa 2004.

54 T. Kamiński, J. Ciesielska-Klikowska, Germany, [in:] The role of regions in EU-China relations, ed. T. Kamiński, Wydawnictwo Uniwersytetu Łódzkiego, Łódź, 2021, p. 45-53. 
International cooperation of German cities (N-76)

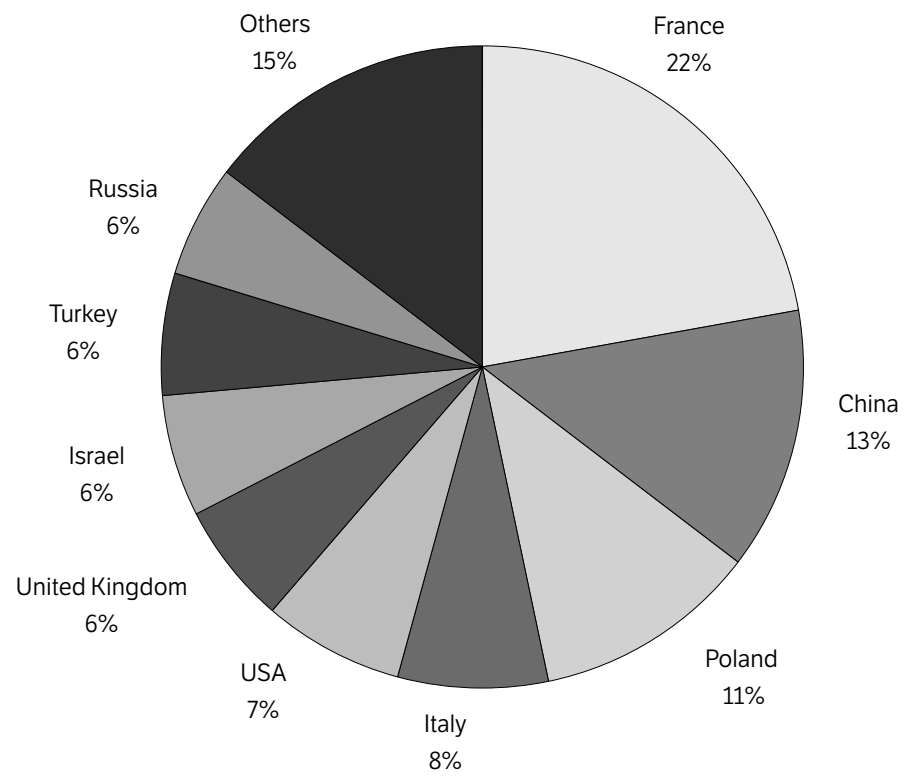

Chart 2. Countries with which Germany most often cooperates at the city level (indication of cities that took part in the survey)

Source: own elaboration based on survey responses (2020/2021).

Yet, as many as 46 out of 79 surveyed cities $(58,2 \%)$ indicated that they had signed some sort of partnership/cooperation agreements specifically with municipalities in China - this number will therefore be a reference point for further analysis (see Table 1). Out of 46 cities that indicated that they collaborate with Chinese municipalities, as many as 12 cooperate with more than one city - Solingen, Duisburg, Frankfurt am Main, and Wolfsburg cooperate with four cities each, while Munich, Mannheim and Krefeld with three cities. The towns of Kaiserslautern, Greifswald, Essen, Wuppertal and Dresden cooperate with two cities in the People's Republic of China. These third and fourth partnerships are relatively recent - they were usually signed in the last few years. According to surveys, most of the newest partnerships have not been well established yet, which is often blamed on the coronavirus epidemic, that also harmed city-to-city relations. 


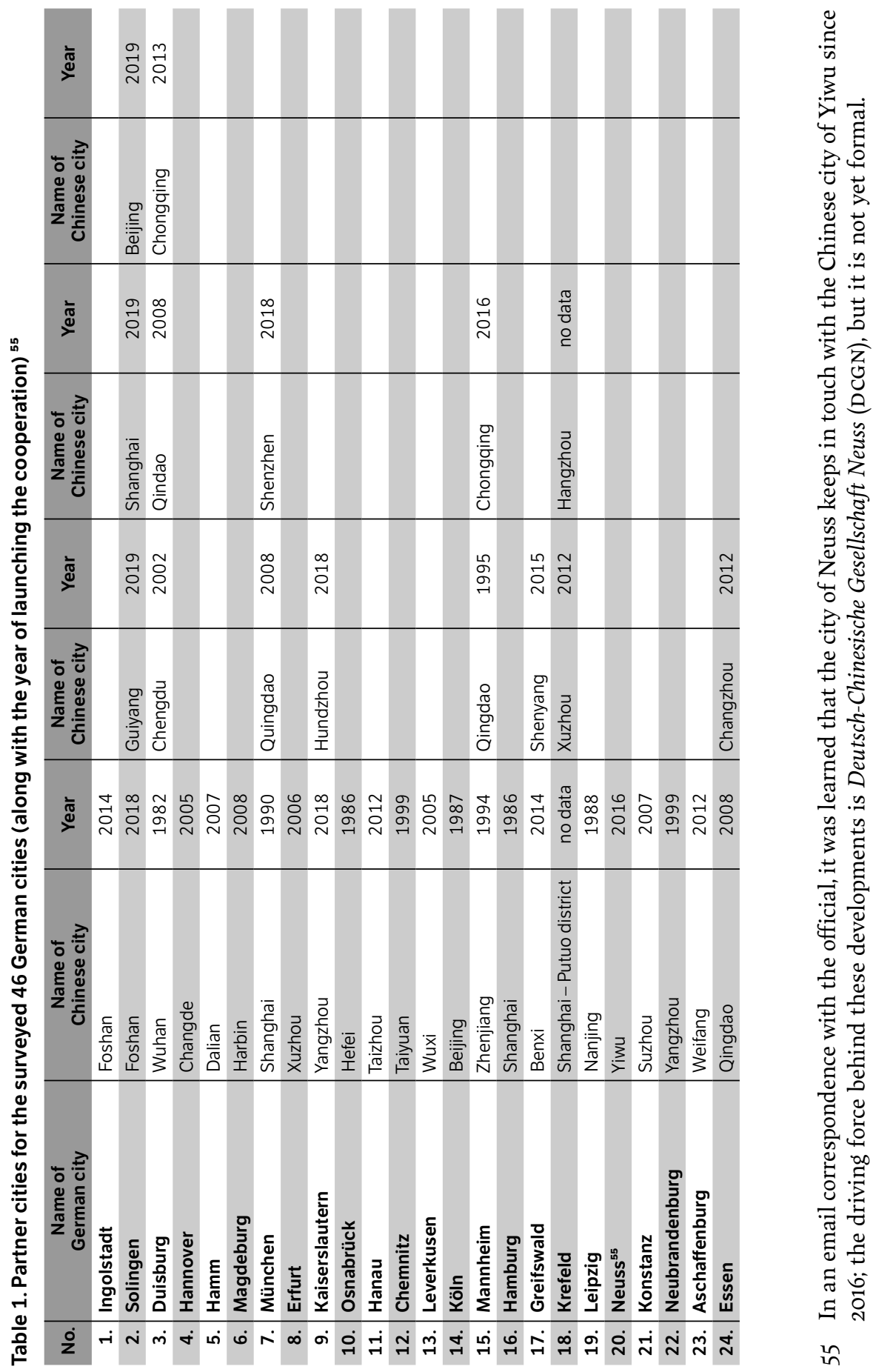


JOANNA CIESIELSKA-KLIKOWSKA

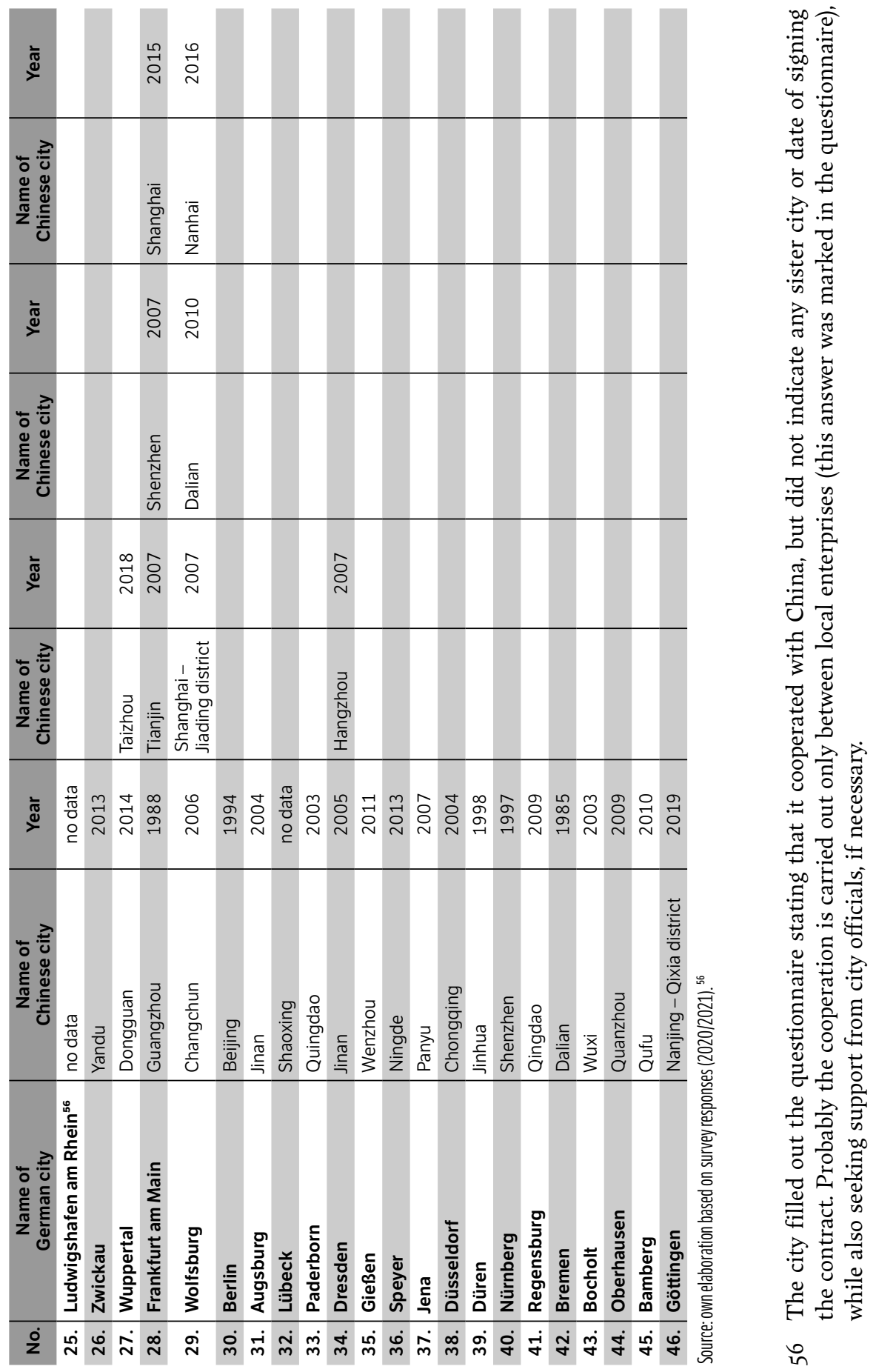


Considering the weight of city-to-city relations, only 7 out of 46 municipalities emphasised that it is a vital partnership $(15,2 \%)$. Significantly in this context, only 35 cities replied that all their associations with China are active $(76,1 \%)$, which means that joint actions have been undertaken in the last two years. Many cities have formal agreements with all their partners in China (26 cities), while the rest have partnership agreements with only some or with no city. This means that the cooperation proceeds thanks to contacts between institutions (schools, universities, cultural centres etc.), but it is not formal. Notably, most surveyed cities have signed official partnership agreements of town-twinning (Städtepartnerschaft), but selected ones have only friendship agreements (Städtefreundschaft). As can be inferred from the responses to the survey, for some city officials this distinction is unclear, and they indicate partnerships also with those cities with which they only have a "formal friendship". However, this difference is vital. Städtepartnerschaft is an official partnership between two towns, municipalities, or regions to exchange cultural and economic information. Städtefreundschaft, on the other hand, is a weaker form of city partnership. It is usually limited in time or relates only to the realisation of particular projects. The term Städtekontakt is also common, yet it describes an even weaker form of city contact, which is only a loose relationship between two cities or municipalities. Some officials tried to add in the survey that the cooperation was less official (e.g. collaboration between schools), but it was generally noted that some form of partnership with Chinese cities was signed.

An interesting picture emerges from the analysis of who initiated the cooperation (see Chart 3). Over half of the surveyed cities replied that it was the German city administration (25 responses), and more than $1 / 4$, these were Chinese local authorities (13 responses). Local business partners and the academic community were ranked next. Moreover, the respondents indicated that these were initiatives of local Chambers of Commerce and Industry (Industrie- und Handelskammer, IHK), organisers of local fairs, or private associations. The city of Leipzig, on the other hand, indicated that the decision to cooperate with Nanjing was political and was made by the authorities of the German Democratic Republic back in 1988, but the partnership continued even after the reunification of Germany. An interesting comment was given by the city of Duisburg, which was the first to establish municipal contacts with China. The official indicated that the person initiating the international cooperation was a teacher 
at the German factory school in Wuhan together with the project manager from Demag, one of the world's leading manufacturers of high-performance industrial cranes, which at that time built a factory in Wuhan. This proves that the initiation of contact may go beyond the political milieu, responding to the needs of local business and the educational community.

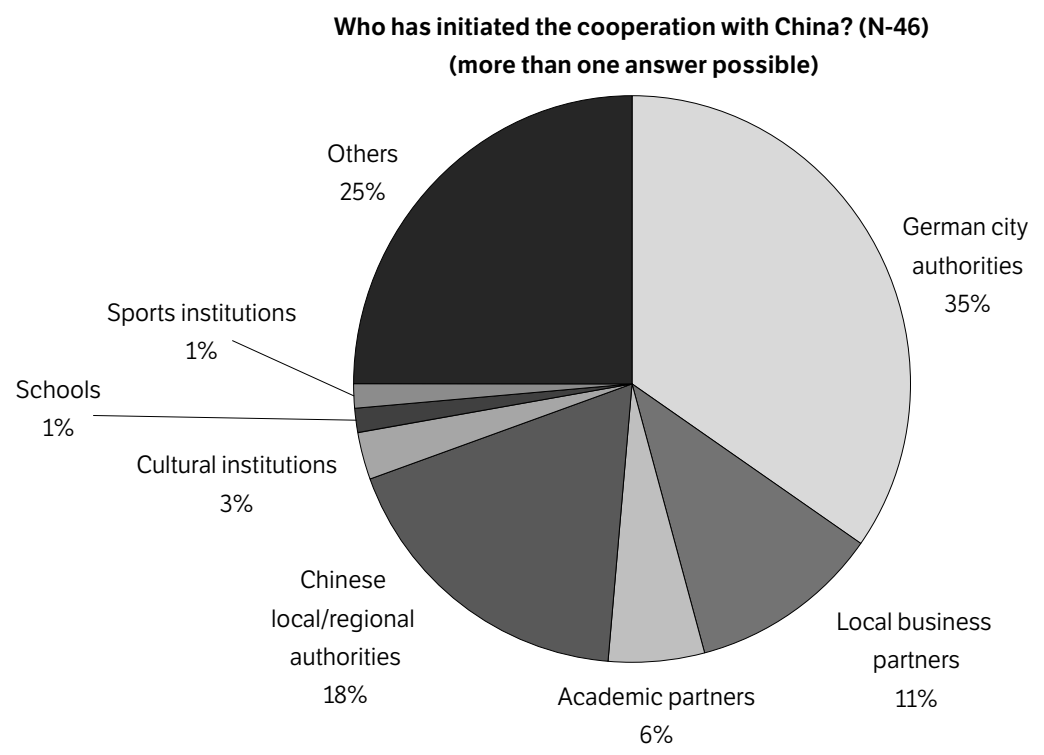

Chart 3. Initiating city-to-city cooperation

Source: own elaboration based on survey responses (2020/2021).

Although, as can be seen from the above, local authorities from both countries are the main initiators of city cooperation, the crucial area of cooperation is the economy ( 36 responses), followed by the cultural sector (34 responses) (see Chart 4). Joint work of the city administration stands in sixth place ( 15 responses), after education (27 responses), academic cooperation (26), sport and tourism (22). In this area, some cities also indicated other possibilities of collaboration, e.g. apprenticeships, organisation of fairs or cooperation of uniformed services (i.e. police).

The issue of collaboration with other local entities concerning cooperation with Chinese cities is also interesting (see Chart 5). When asked if "the cooperation with Chinese partners also engage other local institutions from your region?" as many as 34 of respondents indicated educational institutions. Universities and local cultural centres were ranked next 
What are the areas of cooperation with Chinese partners? (N-46) (more than one answer possible)

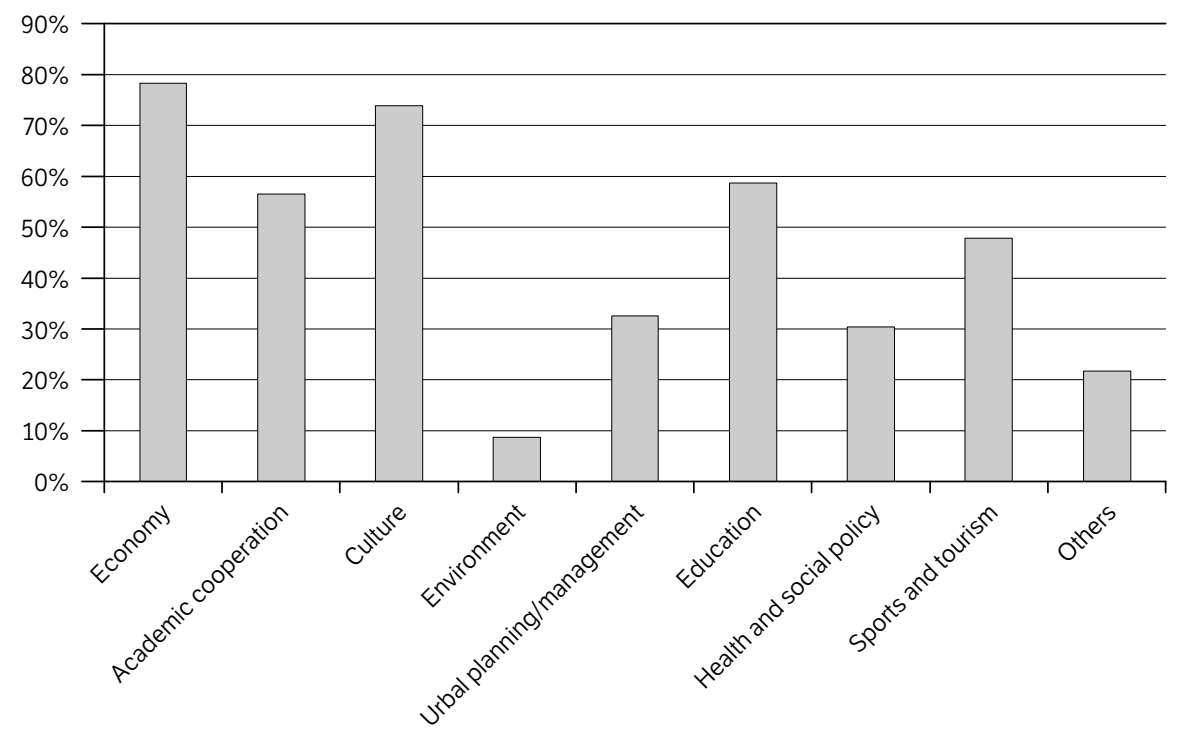

Chart 4. Areas of German-Chinese city cooperation

Source: own elaboration based on survey responses (2020/2021).

Does the cooperation with Chinese partners also engage other local institutions from your region? ( $\mathrm{N}-46)$

(more than one answer possible)

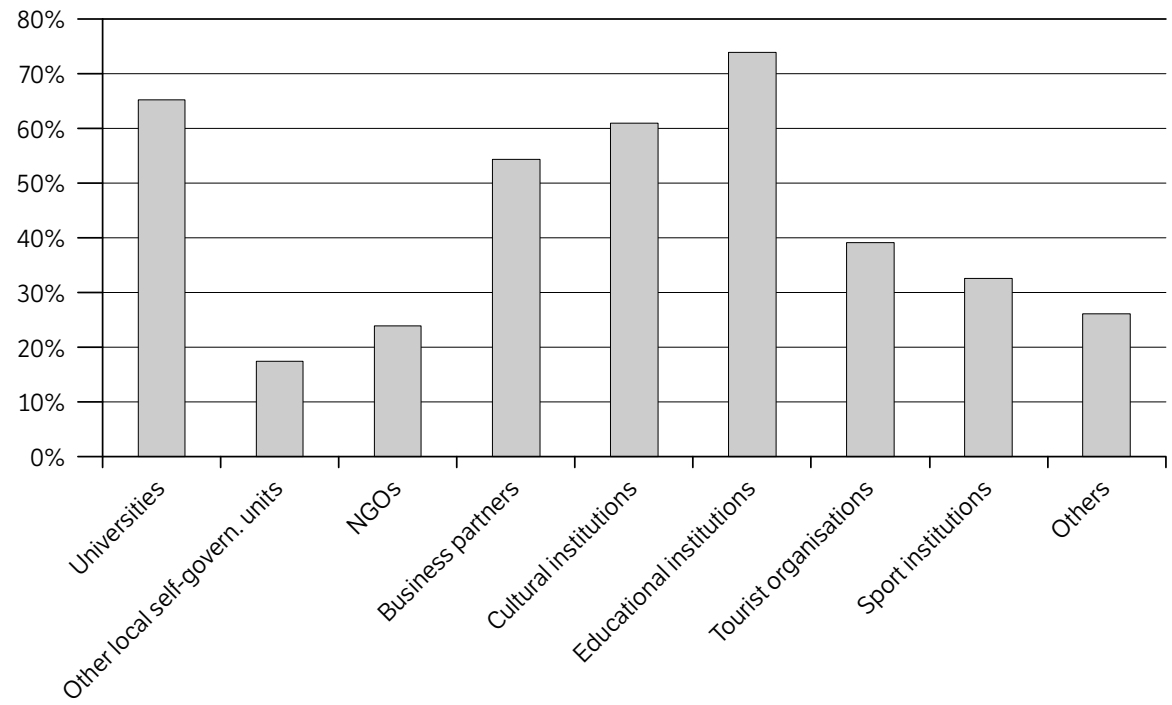

Chart 5. Cooperation with other local institutions

Source: own elaboration based on survey responses (2020/2021). 
(30 and 28 responses respectively). This points to a powerful educational and scientific component in German-Chinese relations at the sub-national level. The issue of intercultural cooperation is significantly integrating and attractive for partners from both countries ${ }^{57}$. At the same time, it is far from political turbulence and can be implemented with regard to different age groups and at all levels of education.

When asked about forms of cooperation with Chinese partners, most cities indicated that meetings of officials (43 responses), participation in fairs and economic forums ( 25 responses) and trade missions (23 responses) were of crucial importance. Establishing a city representative office in China was considered less important (9 responses), as was having a Chinese representative office in a German city (4 responses). However, over $1 / 5$ of cities indicated the significance of active cooperation within networks of cities such as ICLEI or UCLG, which is a clear signal that political cooperation at the bilateral level is crucial, and officials are looking for opportunities to exchange experiences with city representatives around the world.

Anyway, it was the exchange of experiences that the respondents mentioned as the essential profit resulting from cooperation between cities as many as 42 cities indicated this argument when answering the question about the benefits of town-twinning. Moreover, educational exchange was mentioned (37 responses), attracting Chinese investments in the region (23 responses), culture promotion (23 responses) and better position of local companies doing business in China (20 responses). Only $1 / 3$ of the cities indicated tourism promotion, although the statistical data shows evidently that more and more Chinese tourists come to Germany, and cities such as Munich, Berlin, Heidelberg or Trier are favourite destinations for travellers from the Middle Kingdom ${ }^{58}$.

Referring to the biggest obstacles that stand in the way of intensive cooperation, the cities indicated mainly geographical distance ( 38 responses), but also the high costs of cooperation (27 responses), language barriers (18),

57 See also: A. Goette, Q, Gao, Dialog Global. Deutsch-chinesische..., p. 52-68.

58 German Tourist Center indicates that in 2018 more than 3 million overnight stays were booked by tourists from China, which is a significant raise compared to previous years (in 2013 there were 1,74 million overnight stays of Chinese citizens in Germany, in 2015 over 2,54 million). Chinese International Travel Monitor 2018, p. 15. 
differences in the political system (15), and cultural differences (11). Some cities also indicated little involvement of Chinese partners (6 responses) or their own (also 6 responses). Although the geographical distance was in the first place, which is an understandable obstruction, it should be admitted that it is not a barrier to establishing relations. If it were so, China would not be among the key partners for cooperation for German cities (as shown in Chart 2). At the same time, this distance results in other, more down-to-earth problems, mainly related to the high costs of such cooperation (i.e. trips abroad, receiving guests, need to employ a translator). The budgets of many cities for promotion, especially the smaller ones, are pretty modest, so accepting or sending delegations of several or a dozen people is always a heavy burden for the city's treasury ${ }^{59}$.

At the same time, officials believe that the involvement of the Chinese partner is crucial for success in cooperation. The lack of willingness to cooperate and the lack of interest on the Chinese side completely eliminate town-twinning. Therefore, as many as 29 out of 46 respondents indicated the involvement of a Chinese partner as very important. The mayor's attitude to cooperation was in second place - half of the surveyed cities indicated the personal factor as the decisive condition in maintaining relations. Only the following positions were taken by issues such as having an official partnership agreement (21 indications for "very important"), involvement of local companies (14 responses) or the academic community (13 responses).

On the other hand, it is interesting that the cities consider having a permanent office in China as irrelevant to developing intensive cooperation (necessary to a minor extent for 14 cities; not important at all for 9 municipalities); just as the cooperation with the federal government in Berlin (important to a minor extent for 15 towns; not important at all for 6) - the issue of collaboration with the central government was identified as crucial by three cities.

As it turns out, a city mayor interested in cooperation may become the driving force behind the partnership - he/she is the one who most often (together with the educational or business community) initiates collaboration,

59 Freistaat Bayern Haushaltsplan 2017/2018, Einzelplan; Verwaltungsrechnung des Landes Sachsen-Anhalt für das Haushaltsjahr 2009, Gesamtrechnung; K.-J. Nagel, Foreign Policy of Constituent Units..., p. 131. 
but also the duration and intensity of contacts depends on his/her personal involvement. Meanwhile, the lack of cooperation with the central government is not surprising and is mainly due to the extensive autonomy of the Bundesländer and German cities operating within them.

Among other factors influencing successful cooperation, the following issues were mentioned (listed in the "others" section): existing joint projects; contact person in a city administration; frequent communication (e.g. by emails); exchange of information; partnership associations that are interwoven with the city at the civic level; mutual trust; a close and friendly exchange between colleagues on the German and Chinese side; mutual appreciation and respect. These are exciting indications that emphasise that building a network of contacts (essential in both German and Chinese culture), mutual trust, an atmosphere of friendship and respect are also necessary factors strengthening cooperation. Therefore, building city-to-city contacts is not limited only to bureaucracy but must be filled with a good atmosphere and connections. If this is missing, collaboration becomes passive.

\section{Impact of city diplomacy on actions undertaken by the federal authorities}

Germany is a very inclusive federal country in terms of paradiplomacy, and the sub-state entities may participate in the country's foreign relations ${ }^{60}$. Due to this fact, the consequences of paradiplomacy are favourable for the development of the nation as a whole and lead to the rationalisation ${ }^{61}$ and democratisation ${ }^{62}$ of the decision-making process in the national foreign policy ${ }^{63}$. At the same time, authorities and the inhabitants of the cities are aware of their responsibility for the future of the local community and are involved in the process of shaping its political, economic,

60 U. Leonardy, The institutional structures...; C. Jeffery, Recasting German federalism...

61 Rationalisation refers to the principle of subsidiarity, meaning that the central government ought to delegate all tasks that can be effectively performed to the subnational level.

62 Democratisation refers to the plurality of ideas in the decision-making process.

63 J. A. Schiavon, Comparative paradiplomacy, Routledge Abingdon-Oxon-New York 2018, p. 47. 
educational and cultural position. This bottom-up dimension is, in fact, a characteristic indicator for Germany. As former German Foreign Minister Hans-Dietrich Genscher underlined: "Citizens can sometimes achieve more by personal involvement at a private level than we politicians do, especially when the time for official contracts is perhaps not ripe enough" ${ }^{\prime \prime 4}$.

At this point, however, it should be noted that it is difficult to analyse the influence of cities on German foreign policy in isolation from the policies of individual regions because these two groups of entities strongly depend on each other ${ }^{65}$. Therefore, it should be noted that the German political system opens broad fields of practical cooperation between substate entities, complementing the intensive collaboration between the governments and the local authorities. Hans J. Michelmann notes that one of the most important features of German sub-state external relations activities is its complementary character to actions of the government in Berlin ${ }^{66}$. Regional authorities do not challenge the federal government's primacy in German foreign policy but are able to try to cooperate and support it. Indeed, Germany follows a cooperative-coordinated pattern, where regions and cities are involved in international relations under formal or informal coordination with the federal government ${ }^{67}$.

In their international activities, local authorities can count on support from the central administration. The 2015 guidelines entitled "Partner in a world of cities" (Germ. Partner in einer Welt der Städte) state that the federal government wants to help that cities and urban regions use their potential to design a prosperous society that would be poverty-free, aware of its economic potential and safe in the context of environmental challenges. Berlin sees urbanisation in an increasingly networked world as an opportunity for sustainable development (at home and abroad $)^{68}$. At the same time, the government does not impose top-down

64 E.-A. Ziegler, Kommunale Außenpolitik..., p. 184.

65 T. Kamiński, J. Ciesielska-Klikowska, Germany..., p. 41-45.

66 H. J. Michelmann, Länder Paradiplomacy, "German Politics \& Society" 1988, no. 15, p. 30.

67 P. Soldatos, An explanatory framework for the study of federal states as foreign-policy actors, [in:] Federalism and international relations, eds H. J. Michelmann, P. Soldatos, Clarendon Press, Oxford 1990, p. 38-40.

68 Die Bundesregierung, Partner in einer Welt der Städte Leitlinien der Bundesregierung zur internationalen Zusammenarbeit für nachhaltige Urbanisierung, May 2015. 
solutions - any specific models or forms of cooperation ${ }^{69}$. Thus, this relationship between the actions of cities and the federal government is quite vague and hard to notice by municipal authorities.

In the conducted surveys, cities were also asked about the issues of coordinating their international activities with the federal government in Berlin and with the European Union. Only 9 cities replied that they coordinated their international activities somehow with Berlin (but only one city indicated that it coordinated utterly). In fact cities, to a greater extent, coordinate their international policy with each other (17 responses in total) than with the federal government, and even less so with the European Union (the answer "does not coordinate at all" was indicated by as many as 32 surveyed cities). Most cities do not see their influence on the policy of the European Community (30 cities selected "no impact at all" response) and only minimally see their impact on the policy implemented by the government in Berlin (2 answers positively assessing this aspect, 13 cities consider influence as very small, the rest rate their influence as zero). What is very important, however, the cities see a very clear connection and influence of their policies on the international activities pursued by the federal states and vice versa. Half of the surveyed cities (23) indicated that they saw a direct impact of their actions on steps taken by regional authorities.

In practice, therefore, cities emphasize the importance of cooperation with regions, but do not see a close connection with the actions of the federal government, which in fact does not control their international activities in any way. As one of the officials in the German Ministry of Foreign Affairs admitted: "It's not among federal government's responsibilities to have a systemic overview on international cooperation of the sub-state entities. Due to the constitutional barrier, the Länder- and Kommun-level are independent. When trying to implement the monitoring system of the international activities of the communes, you could come close to requiring the regional officials to register everything with the federal government. This would end up sounding like needing the authorisation to do anything, which is not what we're hoping to achieve" ${ }^{\prime 70}$. This peculiar systemic dichotomy has also been noticed by researchers. Ernst-Andreas Ziegler coined even the term

69 T. Kamiński, J. Ciesielska-Klikowska, Germany..., p. 42.

70 Interview with German diplomat, Berlin, 17 April 2019. 
"bypassing the foreign policy of the federal government" (By-Passing der Aussenpolitik $)^{71}$, underlining that cities and states may avoid the collaboration with the federal government to craft their own international policy agreements and contracts ${ }^{72}$, or - on the other hand - they can provide additional support for the conduct of state policy.

It, therefore, seems that this potential for urban cooperation is often untapped, both on the part of the cities and the federal government. Meanwhile, the systemic tools and competencies are extensive, and the use of cities (and regions as well) as "transmission belts" to promote essential values and interests for Germany could bring enormous benefits to the national and international community. Roderick Parkes pointed out accurately that cities are a "hidden capacity" for international politics ${ }^{73}$. Although their vast impact on the economy has been under discussion for several decades, their potential for creating relations at the international level is hardly noticed.

Considering the context of relations with China, such use of lowlevel contacts would provide insight into the plans of the Chinese side. Although the People's Republic of China is a state centrally controlled by the authorities in Beijing, and cities and provinces are perceived as "pawns" in the international game, it should be noted that it is the same "pawns" that start each game on the signal of country's leaders ${ }^{74}$. Therefore, it can be assumed that the intentions of partners from Chinese cities will be in line with the objectives of the authorities in Beijing. This may be an important prognostic for the implementation of policy at the state level, a signal that should not be ignored. Therefore, when concerns about politically motivated Chinese investments have been growing for several

71 E.-A. Ziegler, Kommunale Außenpolitik..., p. 185.

72 The intensive contacts between Bavaria and Austria in 2000, after the elections won by the FPö under the chairmanship of Jörg Haider, are an example of the foreign policy pursued by the German federal state, while the federal government declared jointly and severally the boycott of Austria on the international arena. D. G. McNeil Jr., As the pariah of Europe, Austria seems unbowed, "The New York Times" [online], 14 II 2000 [accessed: $01 \mathrm{~V} \mathrm{2021]}$, available at: <https://archive.nytimes.com/www. nytimes.com/library/world/europe/o2140oaustria-politics.html $>$.

73 R. Parkes, City diplomacy. The EU's hidden capacity to act, available at [accessed: 27 IV 2021]: 〈https://dgap.org/en/research/publications/city-diplomacy>.

74 See: D. Mierzejewski, China's Provinces and the Belt and Road Initiative, Routledge, London 2021. 
years, representatives of local governments should be involved in monitoring Chinese investment activity in Europe.

On the other hand, the authorities should also be aware of possible threats from Chinese partners - in particular, those cities that intensively seek Chinese investors must be aware that they may become a natural target of hostile actions, the aim of which may be to deliberately destabilise the political situation in a given city or region (e.g. by announcing an investment and creating jobs or abandoning the idea unexpectedly). With the increase in globalisation and international interactions, this form of political mistreatment may rise, although it is still relatively poorly described topic in the scientific literature.

Without underestimating the concerns, it should be emphasised that the cooperation of cities brings many benefits. Municipalities - as confirmed by the surveys conducted - often cooperate in the so-called "low politics areas" that are independent of turbulence at a high political level, at the same time deal with universal themes (education, culture, scientific development) and can keep the bloodstream of international relations in good condition. City authorities are also usually closely related to their counterparts in the partner cities. Therefore, it can be assumed that the political, economic and social changes taking place there will be felt by them much faster than by government officials. Thus, cities can act as "antennas", collecting signals for change and acting as whistleblowers in the foreign policy pursued by the state $\mathrm{e}^{75}$. The observation that cities fill the foreign policy implemented by the state with real-life was noticed a few years ago by the President of the Bundestag, Rita Süssmuth, who stated that: "the fact that our foreign policy has not only remained an exchange of communiqués and declarations but that people have come closer to each other, we owe to a very substantial part of the town-twinning ${ }^{\prime 76}$.

\section{Conclusions}

Summing up the research, it should be stated that the international cooperation of German cities with Chinese municipalities has been developing for

75 R. Parkes, City diplomacy..., p. 6-7.

76 E.-A. Ziegler, Kommunale Außenpolitik..., p. 185. 
four decades. However, the biggest waves of interest in making contacts with Chinese cities followed in the early 1990 (after the reunification of Germany), after 2004 (signing of the Strategic Partnership in Global Responsibility), and then after 2014 (signing of the Comprehensive Strategic Partnership).

Of the 79 cities analysed, more than half have intensive relationships with at least one Chinese city, and 12 with more than one. Its essential animators are local authorities, cooperating in this matter with local schools and universities as well as local business. Besides, it is precisely cooperation in the field of economy, education and culture that is crucial in bilateral relations. Cities appreciate the importance of official visits and signing formal contracts while pointing out that having a city office in China and vice versa is not a prerequisite for a successful partnership. At the same time, officials emphasise that the human factor is of great significance specifically the mayor's commitment (on both sides), a friendly atmosphere and mutual trust.

The research shows a surprising indicator describing a little relationship between local government policy and the policy at the state level, and even more so at the European level. Only a small percentage of cities see a direct conversion of their actions into the policy pursued by the government in Berlin or, more broadly, by the institutions of the European Union. Meanwhile, in the EU-China relationship, sub-state activities can be an important instrument in creating norms and principles vital from a European perspective, such as human and labour rights or environmental standards ${ }^{77}$. Therefore, Europe could use cities and regions as "transmission belts" to promote its values, which would also mean applying foreign policy tools in cooperation with local and regional authorities. It would be a good use of the existing resources of city cooperation to implement the provisions of the EU-China Strategy from 2016, in which issues such as sustainable development or people-to-people links are key elements of collaboration between both entities ${ }^{78}$.

77 A. Fulda, The emergence of citizen diplomacy in European Union-China relations: principles, pillars, pioneers, paradoxes, "Diplomacy \& Statecraft" 2019, vol. 30 (1), p. $188-216$.

78 European Commission and High Representative of the Union for Foreign Affairs and Security Policy, Joint Communication to the European Parliament the Council. Elements for a new EU strategy on China, Brussels, 22.6.2016 JOIN(2016) 30 final. 
This seems to be an essential weakness. Considering how rapid urbanisation is progressing (primarily in Asia, with particular emphasis on eastern China), the search for opportunities to coordinate policies implemented at the city level with those carried out at the state level or at the level of international organisation such as the EU may be a valuable step forward. Although cities perform mainly low-policy tasks, local government officials often have close professional relationships with sister cities officials. They should have an "eye and ear" sensitive to changes taking place there - both in their positive and negative aspects. It seems that using this knowledge could bring many benefits for the domestic and foreign policy.

\section{Bibliography}

2018 revision of the world urbanization prospects, United Nations, Department of Economic and Social Affairs, Population Division, available at [accessed: 20 IV 2021]: $\langle$ https://www.un.org/development/desa/publications/2018-revisionof-world-urbanization-prospects.html .

Acuto M., Global cities, governance, and diplomacy, Routledge, London 2013.

Acuto M., Global cities. Gorillas in our midst, "Alternatives: Global, Local, Political" 2010, vol. 35(4).

Agnew J., The territorial trap. The geographical assumptions of international relations theory, "Review of International Political Economy" 1994, no. 1(1).

Alger C. F., The world relations of cities. Closing the gap between social science paradigms and everyday human experience, "International Studies Quarterly" 1990, vol. 34(4).

Athenstaedt Ch., Die Kompetenzverteilung in der deutschen staatlichen Entwicklungszusammenarbeit Zur Zulässigkeit entwicklungsspolitischer Maßnahmen deutscher Bundesländer und Kommunen, Herbert Utz Verlağ, München 2011.

Barber B., If mayors ruled the world. Dysfunctional nations, rising cities, Yale University Press, New Haven 2013.

Bulmer S., Jeffery Ch., Paterson W. E., Germany's European diplomacy. Shaping the regional milieu, Manchester University Press, Manchester 2010.

Die Bundesregierung, Partner in einer Welt der Städte Leitlinien der Bundesregierung zur internationalen Zusammenarbeit für nachhaltige Urbanisierung, May 2015.

Centenary of the International Municipal Movement, UCLG, available at [accessed: 25 IV 2021]: 〈https://www.uclg.org/en/centenary $\rangle$.

Chinese International Travel Monitor 2018, Hotels.com.

Ciesielska-Klikowska J., Germany's attitude towards the Belt and Road Initiative. The impact of non-state actors on German foreign policy towards China, [in:] The Belt and Road Initiative. An old archetype of a new development model, eds P. A. B. Duarte, F. B. S. José Leandro, Springer, Singapore 2020. 
Cornago N., On the normalisation of sub-state diplomacy, "The Hague Journal of Diplomacy" 2010, vol. 5 (1-2).

Cornago N., Plural diplomacies: Normative predicaments and functional imperatives, Martinus Nijhoff Publishers (Diplomatic Studies, 8), Leiden 2013.

Curtis S., Cities and global governance. State failure or a new global order?, "Millennium" 2016, vol. 44(3).

Deutscher Städtetag, Positionspapier. Kommunen im Bundesstaat stärken, sygn. 30/05/16.

Dijkstra L., Poelman H., Cities in Europe. The new OECD-EC Definition, European Commission, Regional Focus, nr 01/2012.

Duchacek I., The international dimension of subnational self-government, "The Journal of Federalism" 1984, vol. 14, issue 4.

European Commission and High Representative of the Union for Foreign Affairs and Security Policy, Joint Communication to the European Parliament the Council. Elements for a new EU strategy on China, Brussels, 22.6.2016 JOIN(2016) 30 final. Freistaat Bayern Haushaltsplan 2017/2018, Einzelplan.

Friedmann J., The world city hypothesis, "Development and Change" 1986, vol. 17(1). Fulda A., The emergence of citizen diplomacy in European Union-China relations: principles, pillars, pioneers, paradoxes, "Diplomacy \& Statecraft" 2019, vol. 30 (1).

Goette A., Gao Q.. Deutsch-chinesische Kommunalbeziehungen, Servicestelle Kommunen in der einen Welt (Dialog Global, 19), Bonn 2019.

Held U., Merkle R., Deutsch-chinesische Kommunalbeziehungen. Motivationen, Strukturen, Aktionsfelder, Servicestelle Kommunen in der einen Welt (Dialog Global, 19), Bonn 2008.

Hocking B., Patrolling the 'frontier'. Globalization, localization and the 'actorness' of non-central governments, [in:] Paradiplomacy in action. The foreign relations of subnational governments, eds F. Aldecoa, M. Keating, Routledge, London-New York 1999.

Huimin S., Yi W., Chuntai W., Lu H., China's relations with West European countries, "Studia Diplomatica" 1996, vol. 49 (4/5).

Interview with German diplomat, Berlin, April 172019 (recording of the conversation in the author's collection).

Jeffery C., Recasting German federalism. The legacies of unification, Friedrich Ebert Stiftung, London 1999.

Joint Declaration between Germany and China, 28. März 2014, Presse- und Informationsamt der Bundesregierung, available at [accessed: 22 IV 2021]: $<$ https://archiv.bundesregierung.de/archiv-de/meta/startseite/joint-declarationbetween-germany-and-china-460244>.

Kamiński T., Ciesielska-Klikowska J., Germany, [in:] The role of regions in EU-China relations, ed. T. Kamiński, Wydawnictwo Uniwersytetu Łódzkiego, Łódź, 2021.

Kamiński T., Ciesielska-Klikowska J., The sub-national dimension of the European Union's relations with China: A Solution for Tough Times?, [in:] Europe in an era of growing Sino-American competition. Coping with an unstable triangle, eds S. Biba, R. Wolf, Routledge, London 2021. 
Keohane R., Nye J., Power and interdependence, "Survival" 1973, vol. 15:4.

Keohane R., Nye J., Power and interdependence. World politics in transition, Little, Brown and Company, Boston 1989.

Kuznetsov A.S., Theory and practice of paradiplomacy. Subnational governments in international affairs, Routledge, London-New York 2015.

Langenohl A., Town twinning, transnational connections, and trans-local citizenship practices in Europe, Palgrave Macmillan, Basingstoke 2016.

Leonardy U., The institutional structures of German federalism, London 1999 (electronic ed.), available at [accessed: 20 IV 2021]: <http://library.fes.de/fulltext/ bueros/london/00538007.htm\#E10E15>.

Ljungkvist K., The global city 2.0. From strategic site to global actor, Routledge, London 2015.

Michelmann H. J., Länder paradiplomacy, “German Politics \& Society” 1988, no. 15.

Michelmann H. J., Soldatos P., Federalism and international relations. The role of subnational units, Clarendon Press Publication, Oxford 1991.

Mierzejewski D., China's provinces and the Belt and Road Initiative, Routledge, London 2021.

Migration, urbanization, and development. New directions and issues, ed. R. E. Bilsborrow , Springer, Dordrecht 1998.

Morgenthau H., Politics among nationsMcGraw-Hill, New York, 1949.

Nagel K.-J., Foreign policy: the case of the German lander, [in:] Foreign policy of constituent units at the beginning of 21st century, ed. F. Requejo, Generalitat de Catalunya, Institut d'Estudis Autonòmics, Barcelona 2010.

Nijman J. E., Renaissance of the city as global actor, [in:] The transformation of foreign policy, eds G. Hellmann, A. Fahrmeir, M. Vec,Oxford University Press, Oxford 2016.

Parkes R., City diplomacy. The EU's hidden capacity to act, available at [accessed: 27 IV 2021]: 〈https://dgap.org/en/research/publications/city-diplomacy>.

Parysek J. J., Duże miasta Europy $i$ ich rola w procesie urbanizacji, rozwoju społecznogospodarczego i europejskiej integracji u schyłku XX wieku, „Przegląd Geograficzny” 1995, T. LXVII, z. 3-4.

Pigman G. A., Contemporary diplomacy, Polity Press, Cambridge 2010.

Plöhn J., Steffani W., Bund und Länder in der Bundesrepublik Deutschland, [in:] Handbuch der deutschen Bundesländer (2nd ed.), ed. J. Hartmann, Bundeszentr. für Polit.Bildung, Bonn 1994.

Roters J., Wolf F., Städtekooperation und Städtediplomatie im Nahen Osten am Beispiel der Stadt Köln, „Zeitschrift für Außen- und Sicherheitspolitik“ 2013, vol. 6 , no. 3 ,

Schiavon J. A., Comparative paradiplomacy, Routledge, Abingdon-Oxon-New York 2018.

Schweizer R. J., Brunner S. C., Die Mitwirkung der Bundesländer an EU-Vorhaben in der Bundesrepublik Deutschland und in Österreich: ein Modell für die Mitwirkung der Kantone in der Aussenpolitik, Stämpfli Verlag AG, Bern 1998. 
Skorupska A., Szczudlik J., EU-China paradiplomacy - the perspective of cities, regions and provinces, [in:] The role of regions in EU-China relations, ed. T. Kamiński, Wydawnictwo Uniwersytetu Łódzkiego, Łódź, 2021.

Soldatos P., An explanatory framework for the study of federal states as foreign-policy actors, [in:] Federalism and international relations, eds H. J. Michelmann, P. Soldatos, Clarendon Press, Oxford 1990.

Statz A., Wohlfarth Ch., Kommunale Partnerschaften und Netzwerke. Ein Beitrag zu einer transnationalen Politik der Nachhaltigkeit, Heinrich-Böll-Stiftung, Berlin 2010.

Szmigiera M., Urbanization by continent. Degree of urbanization (percentage of urban population in total population) by continent in 2020, Statista 2021, available at [accessed: 26 VII 2021]: <https:/www.statista.com/statistics/27086o/ urbanization-by-continent/>.

Szymańska D., Urbanizacja na świecie, Wydawnictwo Naukowe PWN, Warszawa 2008. Tacoli C., Migration and inclusive urbanization, United Nations Expert Group Meeting on Sustainable Cities, Human Mobility and International Migration, UN/POP/EGM/2017/6, 5 September 2017.

Tavares R., Paradiplomacy, cities and states as global players, Oxford University Press, New York 2016.

Trzcielińska-Polus A., Samorządowy wymiar polityki zagranicznej regionów (na przykładzie Śląska Opolskiego), „Pogranicze. Polish Borderland Studies“ 2015, vol. 3, no. 2.

United Nations, Report of the UN economist network for the UN 75th anniversary. Shaping the trends of our time, September 2020.

United Nations Population Division. World urbanization prospects: 2018 revision, World Bank, available at [accessed: 26 VII 2021]: <https://data.worldbank.org/ indicator/SP.URB.TOTL.IN.ZS >.

Urban world. Mapping the economic power of cities, McKinsey Global Institute, March 2011.

Verwaltungsrechnung des Landes Sachsen-Anhalt für das Haushaltsjahr 2009, Gesamtrechnung.

Waltz K., Theory of international politics, Waveland Press, Chicago 1979.

What policies for globalising cities? Rethinking the urban policy agenda, OECD, Madrid 2007.

Wimmer A., Glick-Schiller N., Methodological nationalism and beyond: nation-state building, migration and the social sciences, "Global Networks" 2002, vol. 2 (4).

Wspótpraca transǵraniczna Unii Europejskiej. Doświadczenia Polski i Niemiec, eds G. Gorzelak, J. Bachtler, M. Kasprzyk, Wydawnictwo Naukowe Scholar, Warszawa 2004.

Ziebura G., Die deutsch-französischen Beziehungen seit 1945. Mythen und Realitäten, Klett-Cotta, Stuttgart 1997.

Ziegler E. A., Kommunale Außenpolitik, [in:] Freunde reden Tacheles. Der Beitrag der Städte zur Außenpolitik am Beispiel Deutschland-Israel, ed. E. A. Ziegler, Verlag P. Hammer, Wuppertal 1992. 